\title{
Effect of Harvesting Time and Moisture Content on Energy Consumption of Compressing Switchgrass
}

\author{
Benjamin Kemmerer, Jude Liu \\ Department of Agricultural and Biological Engineering, The Pennsylvania State University, \\ University Park, USA \\ Email: jliu@engr.psu.edu
}

Received 10 August 2014; revised 14 September 2014; accepted 18 October 2014

Copyright (C) 2014 by authors and Scientific Research Publishing Inc.

This work is licensed under the Creative Commons Attribution International License (CC BY). http://creativecommons.org/licenses/by/4.0/

c) (i) Open Access

\section{Abstract}

As a dedicated energy crop, switchgrass may be harvested in fall or early spring depending on weather conditions, field capacities of harvesting machines, storage capacities, field management and availability of machine operators. To reduce storage space demand and increase transportation efficiency, harvested switchgrass should be densified. This research was conducted to examine energy consumption of compressing switchgrass collected from various harvesting seasons. Results indicated that the switchgrass harvested in the spring required the maximum energy consumption to process due to its dry and brittle nature. Conversely, the switchgrass harvested in the fall required less energy to compress due to its higher moisture content and associated reduction in resistive forces. For the same moisture content, fall harvested switchgrass would consume less energy to compress compared to spring harvested due to changes in properties of switchgrass over the winter.

\section{Keywords}

Biomass, Mechanical Properties, Densification, Energy Consumption

\section{Introduction}

The largest challenges in biomass logistics are the transportation and storage costs. Current transportation costs are as high as $\$ 0.18$ - $\$ 0.40$ per $\mathrm{km} / \mathrm{Mg}$ for truck, rail, pipeline, and barge transport methods [1]. Storage costs are usually greater than $\$ 15 / \mathrm{Mg}$ [2]. These costs become substantial when massive quantities of biomass must be transported and stored. Maximizing the transportation and storage efficiencies through densification is critical. 
The bulk density of most plant biomass in loose and uncompressed form is well below $100 \mathrm{~kg} / \mathrm{m}^{3}$ [3]. Large square baler is an effective way to harvest biomass. The bulk density of large square bales is between $150 \mathrm{~kg} / \mathrm{m}^{3}$ [2] and $200 \mathrm{~kg} / \mathrm{m}^{3}$ [4] depending on the capacity of the large square baler used. Using a large square baler to produce bales with higher bulk density is currently being practiced.

Bale compression could be another option after bales are produced. Identification of the relationship between costs of increasing the density of bales and savings incurred during transportation and storage due to the increased densities are necessary to further enable the optimization of large square bale use. This relationship can be acquired by comparing different bale densities in terms of energy and all other associated costs. After the relationship between bale density and energy consumption in bale production is developed, optimal bale densities for different scenarios can be determined.

Harvesting agricultural crops in the form of baled material is currently one of the most effective harvest methods for transporting the material off the farm. It was reported in [2] that the costs associated with large square bale storage under roof ranged from $\$ 16$ to $\$ 19 / \mathrm{Mg}$ for biorefinery plant capacities between 40 and 200 million gallons per year. These costs were based on a bale density of $150 \mathrm{~kg} / \mathrm{m}^{3}$. These costs are universal for all crops with a bale density of $150 \mathrm{~kg} / \mathrm{m}^{3}$. Storage costs can be expected to decrease with increased bale density. Bulk density has a direct influence on many attributes that determine the cost of delivered biomass feedstock to the refinery [5]. Biomass densification is vital to increasing bulk density and therefore reducing transportation and handling costs. Kalminski [6] stated that biomass compression could be simulated with a power model that predicts bulks density as a function of pressure Equation (1). However, the model does not take into account of biomass type, particle size, or moisture content. Further research is needed to accurately quantify the pressures and energy required to compress switchgrass in order to transform it into a viable energy feedstock.

$$
\gamma=k\left(p^{n}\right)
$$

where, $\gamma$ is bulk density $\left(\mathrm{kg} / \mathrm{m}^{3}\right)$; $k$ is constant; $\quad p$ represents pressure ( $\left.\mathrm{kPa}\right)$; and $n$ is exponential constant.

The constants $n$ and $k$ in Equation (1) are specific to each material and must be determined with compression tests. The actual relationship will vary depending on the type of materials, moisture contents, and partial sizes. Densification of soybean straw, dry corn stalks, wet corn stalks, and dry alfalfa hay were compressed in a 0.39 $\mathrm{m}$ in diameter and $0.56 \mathrm{~m}$ in height PVC pipe at a loading speed of $0.127 \mathrm{~m} / \mathrm{s}$ [7]. Crops with a greater percentage of leaf matter can be compressed easier than stalk material [7]. Moisture is a major variable that has a great effect on pressure density relationship of biomass. High moisture contents tend to decrease the friction of biomass particles rubbing against each other during compression. The moisture content of biomass increases, the pressure required to achieve a desired wet bulk density will decrease [7].

Bale compression outside of the field currently holds a niche market for specialty agricultural forage markets. Several manufacturers currently sell bale compressors that slice large square bales into smaller sections and further compress the sections using hydraulic rams. Manufacturers such as Steffen Hay Inc. claim a bulk density of up to $500 \mathrm{~kg} / \mathrm{m}^{3}$ can be achieved with their product [8]. The output of these machines is typically sliced small bales around $35 \mathrm{~kg}$ each that is often stacked in shipping containers. The machines are mostly used for international forage shipping logistics due to the current high costs of compression. Current compression costs average around $\$ 30$ per ton [9].

Large square bale density can be controlled at the time of production, as well as after production. Large square balers have a wide range of density settings to choose from in the field. Densification options after bale production include bale re-compression, pelleting, cubing, and briquetting. Pelleting, cubing, and briquetting are energy intensive processes that may not need to be performed on all switchgrass feedstocks. When switchgrass in the form of large square bales is a satisfactory product for the end user, the density of the bales becomes a significant factor in the logistics production, transportation, handling, and storage of large square bales.

Densification is a fundamental process that is vital to the production of biomass feedstocks. Densification increases the bulk density of biomass, which is necessary to harvest, transport, and store a product that is an economically feasible biomass energy feedstock. Current herbaceous biomass harvest methods produce either chopped loose materials or bales. The literature review recognized baled material as the most readily available form of biomass suitable for current off the farm storage and transportation methods. Of the different types of agriculturally-derived biomass available, switchgrass is recognized as holding the greatest potential as one of the dedicated energy crops in the United States.

Moisture content greatly effects large square bale production. The moisture content at time of harvest must 
not exceed $18 \%$ to $22 \%$ (w.b.) for dry harvest depending on the crop. Moisture contents above this threshold may experience dry matter loses and fire danger from both high respiration rates within the cells of the biomass and mold growth. Low moisture content at time of harvest cause dry matter losses from shattering. Moisture content is known to have a large effect on bale density. Typically, small increases in moisture content cause large increases in bale density if baler setting remains contents. The goal of this compression test was to determine if increasing the moisture content decreases the energy needed for compression due to decreased friction between biomass particles.

The research objective was to determine the effect moisture content and harvest season on energy consumption of compressing switchgrass using lab scale experiments.

\section{Compression Test on Switchgrass of Various Moisture Contents}

\subsection{Switchgrass Sample Collection}

Switchgrass used in the compression tests was collected from a demonstration plot at the Pennsylvania State University agronomy farm in Rock Springs, Pennsylvania. The switchgrass was a Cave-in-Rock cultivar. To mimic a fall harvest situation, the switchgrass was cut and collected manually, leaving three to four inches of stubble. The grass was immediately taken back to the lab to begin testing. The switchgrass was harvested in late September after growth had stopped. The moisture content of standing switchgrass decreases dramatically after the first killing frost. Switchgrass harvested in the fall for biomass is typically mowed after a killing frost in order to make use of the ability of the biomass to dry down while standing. The switchgrass samples collected for the compression testing were cut prior to the first fall frost in order obtain a higher moisture content, $48 \%$ (w.b.).

\subsection{Instrumentation and Measurements}

A compression test stand located in the Department of Agricultural and Biological Engineering at Pennsylvania State University (Figure 1) was used to compress the switchgrass samples. This compression testing stand is a product made by Cooper Instruments and Systems. This stand is capable of producing 89,000 $\mathrm{N}$ of compression force through the use of two vertical hydraulically actuated cylinders that oppose each other as seen in Figure 1. These two cylinders can be operated individually. The stroke of these two cylinders was $20.32 \mathrm{~cm}$. For the compression test in this study, only the top cylinder that extends downward was used. The maximum extension speed of the top cylinder is $28.4 \mathrm{~mm} / \mathrm{s}$.

The stand is equipped with a digital display of displacement and vertical force. The compression force (vertical) was measured with a load cell on the rod end of the cylinder while the displacement was measured with a

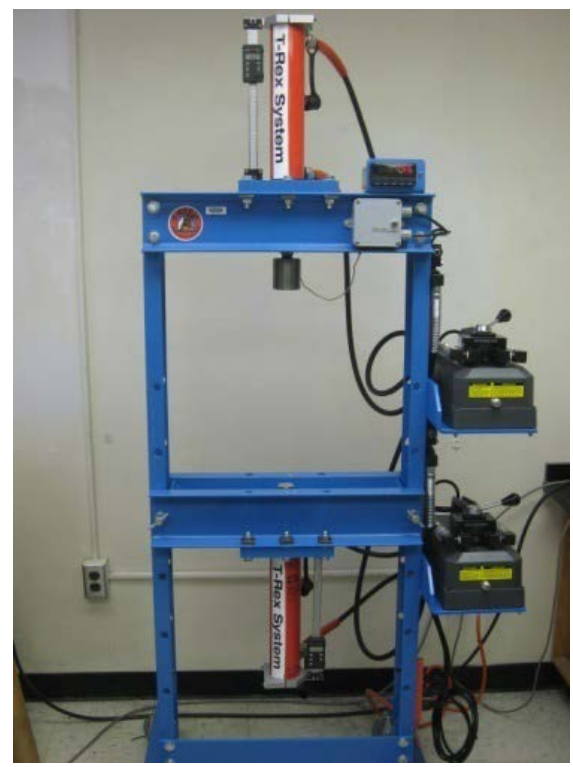

Figure 1. Compression test stand (Cooper Instruments and Systems; maximum vertical load: 1000 kg). 
linear potentiometer. The stand originally came from the manufacturer with only digital readouts of force and displacement. A data logger was used to record force and displacement measurements over time. For the force measurements, the data logger was connected to the load cell that came installed on the machine. The load cell was then calibrated using a proving ring. To gather displacement data, a cable extension transducer was mounted on the compression stand. The cable extension transducer consisted of a potentiometer that measured the distance between the plunger head and a fixed point on the stand. The data logger was able to store time, displacement, and force over the course of each tests. Sampling rate was 16 data per second.

To conduct the compression tests, both a steel compression chamber and a plunger head were manufactured (Figure 2). Preliminary compression tests on switchgrass determined the pressure needed to reach a final density of $500 \mathrm{~kg} / \mathrm{m}^{3}$ was approximately $3400 \mathrm{kPa}$. Since $89,000 \mathrm{~N}$ of force were available from the stand, the maximum area over which the compression force could be applied to was $0.0262 \mathrm{~m}^{2}$. The steel chamber was built with a square $16 \mathrm{~cm} \times 16 \mathrm{~cm}$ open end, resulting in a $0.0256 \mathrm{~m}^{2}$ area over which the compression force would be applied. The depth of the chamber was limited to $20.32 \mathrm{~cm}$ due to the stroke of the cylinder. A plunger head, which applied the compression force to the sample, was made of aluminum. The plunger was designed to slide over the rod end of the compression cylinder and to reduce exerting other forces to the vertical direction. The dimensions of the plunger head were slightly smaller than the opening of the compression chamber to avoid contact between the plunger head and chamber during compression.

\subsection{Experimental Design}

To achieve several different levels of moisture contents, the switchgrass collected from the Pennsylvania State University agronomy farm was spread out inside the department lab for drying. Compression tests were performed approximately every twelve hours over the course of four drying days. Seven different moisture contents were expected. The first set of tests occurred right after the switchgrass was harvested in order to evaluate the high level of moisture content. For the last set of tests, the switchgrass samples were dried in an oven to reach moisture contents lower than what was possible with naturally-dried samples. The first day the humidity averaged $30 \%$ and the grass dried down to $18 \%$ (w.b.). Drying rates for the rest of the three days varied with changes in humidity and temperature.

All the switchgrass used in the testing was manually cut to lengths just under $16 \mathrm{~cm}$ so that the grass could be horizontally oriented in the chamber. The stems and leaves of each switchgrass tiller were all cut just before each test into similar lengths in order to maintain the same ratio of stems and leaves found in the field for every test. While the grass was all horizontally oriented during compression, the stems and leaves were not all perfectly parallel. This orientation was intended to mimic the way switchgrass would be oriented by stuffer forks in the bale chamber of a large square baler. The cut switchgrass was loaded in to the chamber until it was level with the top of the chamber with no mechanical force applied. Initial bulk density was around $70 \mathrm{~kg} / \mathrm{m}^{3}$. The chamber was then placed under the plunger and force was applied until the bulk density in the chamber exceeded $500 \mathrm{~kg} / \mathrm{m}^{3}$. Three replications were performed at each moisture content level. After each replication all the switchgrass was removed from the chamber, placed in a plastic bag, and weighed to determine the mass of the sample in this replication. A new sample was then loaded into the chamber for the next replication. After all

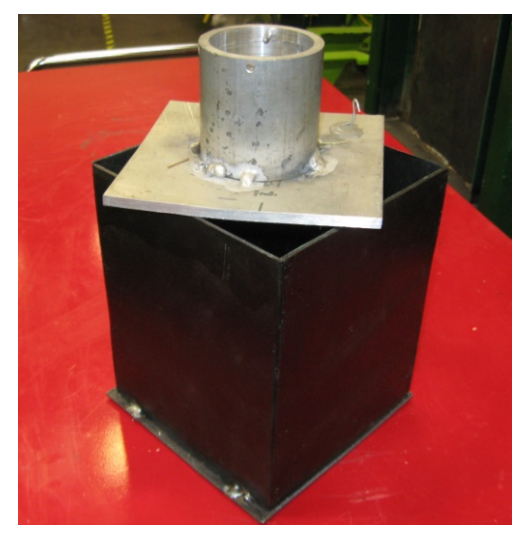

Figure 2. Plunger head and compression chamber used for compressing switchgrass. 
the replications for any particular moisture content were completed, samples from each replication were placed in paper bags and used for moisture analysis. ASABE standards [10] were used in the moisture analysis and all results are reported on a wet basis.

\subsection{Results and Discussion}

The force values for all the data were converted to pressures in kilopascals using the surface area of the plunger. To calculate bulk density, the displacement values were used to calculate the volume of the switchgrass in the chamber that corresponded to each pressure value. The mass of the switchgrass sample in each replication was then divided by the volume values to determine the bulk density for every force and displacement data point collected during the compression stroke of the cylinder.

\subsubsection{Fitting Curves to the Pressure-Density Relationships}

The relationship between measured pressure and bulk density data points can be described with a power curve. Results were graphed from $70 \mathrm{~kg} / \mathrm{m}^{3}$ to $350 \mathrm{~kg} / \mathrm{m}^{3}$. The density of $350 \mathrm{~kg} / \mathrm{m}^{3}$ was chosen as an upper limit because this is approximately the bulk density current large square bale compressors are capable of producing with switchgrass. Excel spreadsheet was used to fit a power curve to the data points from each different moisture content. The equations that describe the curves are an average from three replications performed on each moisture level. The power curves for the dry matter bulk density are described in Equation (2) and parameters are listed in Table 1. The power curves for the wet bulk densities are described in Equation (3) and the constants are given in Table 2.

$$
\begin{aligned}
& \gamma_{\text {dry }}=k\left(p^{n}\right) \\
& \gamma_{\text {wet }}=k\left(p^{n}\right)
\end{aligned}
$$

where $\gamma_{\text {dry }}$ is dry matter bulk density $\left(\mathrm{kg} / \mathrm{m}^{3}\right) ; \gamma_{\text {wet }}$ is wet bulk density $\left(\mathrm{kg} / \mathrm{m}^{3}\right) ; k$ stands for constant; $p$ represents pressure; and $n$ is exponential constant.

As shown in Table 1 and Table 2 exponential constants for all moisture levels of the curves are near constant. However, the $k$ values are consistently higher as the moisture content increases. $k$ values are an indication of how much pressure is required to compress the material. Smaller $k$ values for the dry bulk density curves mean more pressure was needed to increase the bulk density of the material as compared to the wet bulk density curves. All of the $k$ values for the wet bulk density are higher because less pressure was needed to reach any particular density value as compared to the dry matter bulk density pressures. At any point during the compression stroke, the wet matter bulk density was higher than the dry matter bulk density due to the inclusion of water mass in the wet matter bulk density value.

\subsubsection{Fitting Curves to the Pressure-Density Relationships}

Specific energy consumption during compression can be estimated by integrating the area under a compression curve or load-deformation relationship at each moisture content level. By inverting the power curve Equations (2) and (3) described in Table 1 and Table 2 and integrating with respect to pressure, the specific energy requirement of each compression test in $\mathrm{kJ} / \mathrm{kg}$ can be calculated. This integration is illustrated in Equation (4).

Table 1. Power curve parameters for dry matter bulk density.

\begin{tabular}{cccc}
\hline Moisture Content (\% w.b.) & Coefficient (k) & Exponential Constant (n) & 0.95 \\
\hline 4.74 & 42.93 & 0.334 \\
12.60 & 34.19 & 0.374 & 0.380 \\
20.56 & 32.59 & 0.99 & 0.332 \\
22.80 & 42.39 & 0.90 & 0.326 \\
22.83 & 45.37 & 38.53 & 0.99 \\
31.40 & 0.972 & 0.93 \\
48.80 & 38.19 & 0.92 & 0.343 \\
\hline
\end{tabular}


Table 2. Power curve parameters for wet matter bulk density.

\begin{tabular}{cccc}
\hline Moisture Content (\% w.b.) & Coefficient (k) & Exponential Constant (n) & $\mathrm{R}^{2}$ \\
\hline 4.74 & 44.92 & 0.334 & 0.96 \\
12.60 & 54.82 & 0.301 & 0.97 \\
20.56 & 46.86 & 0.352 & 0.98 \\
22.80 & 57.75 & 0.320 & 0.97 \\
22.83 & 47.39 & 0.367 & 0.96 \\
31.40 & 63.00 & 0.331 & 0.88 \\
48.80 & 79.32 & 0.303 & 0.91 \\
\hline
\end{tabular}

$$
\int_{0}^{p} \frac{1}{k\left(p^{n}\right)} \mathrm{d} p=\text { specific energy requirment }\left(\frac{\mathrm{kJ}}{\mathrm{kg}}\right)
$$

The inverted power curve needs to be integrated from a start pressure to a final pressure. At the start of these compression tests, no force was being applied to switchgrass, making the lower bound of the integration zero. To find the specific energy required to compress the sample to the density of $350 \mathrm{~kg} / \mathrm{m}^{3}$, the pressure applied to reach that bulk density needs to be calculated from the power curves. These pressure values form the upper bounds of the integration. All pressures required to produce a density of $350 \mathrm{~kg} / \mathrm{m}^{3}$ are given for both dry matter bulk densities and wet matter bulk densities in Table 3 and Table 4.

The specific energy requirements given in Table 3 and Table 4 are averages of the three replications performed at each moisture content level. A liner regression was performed on the relationship between the specific energy requirements and the moisture content to examine if there is a correlation between these two variables. Linear regression was performed on both the dry matter and wet matter bulk density relationships. Figure 3 shows the results of both linear regressions. Similar with the power curve constants, any data point represents an average of the three replications at one moisture content level.

Figure 3 shows that when only the dry matter content was used to calculate the specific energy, no correlation between the moisture content and the specific energy requirements for compression was found (Figure 3). The dry matter specific energy requirements appear to neither decrease nor increase with increasing in moisture content. The wet matter specific energy requirements, however, clearly decreased when increasing the moisture content.

\section{Compression Test on Fall and Spring Harvested Switchgrass}

\subsection{Spring Harvested Switchgrass Collection}

Samples of switchgrass from a commercial switchgrass farm (Ernst Seeds) located in eastern Pennsylvania were collected in the first week of May for compression tests. These samples represented spring harvested switchgrass. The samples tested in Section 2 represented the fall harvested switchgrass. The switchgrass from the spring harvest were tested in the same manner as those tests in Section 2. Both the fall and spring switchgrass were a Cave-in-Rock variety. The only difference between the samples from the different farms was the time of harvest. The spring switchgrass from the commercial farm was mowed in November, overwintered on the ground, and collected samples from windrow in early May. Moisture content was constant for all fall harvest samples. The compression test stand and the compression chamber, plunger, data acquisition system were the same as used in Section 2.

\subsection{Results}

The switchgrass from spring harvest was compressed to examine the impact of harvest season on the specific energy requirements of compression. The spring switchgrass was compressed in three different sets of tests to examine the compression force and density relationships, which were represented with power curves. All of the power curves in the spring switchgrass compression test have significantly lower $k$ values compared to fall harvested switchgrass. This indicated that the spring harvested switchgrass was much harder to compress than the 
Table 3. Specific energy requirements to reach $350 \mathrm{~kg} / \mathrm{m}^{3}$ dry matter bulk density.

\begin{tabular}{ccc}
\hline Moisture (\% w.b.) & Pressure to reach $350 \mathrm{~kg} / \mathrm{m}^{3}(\mathrm{kPa})$ & Specific Energy Requirement $(\mathrm{kJ} / \mathrm{kg})$ \\
\hline 4.74 & $529.14^{*}$ & $2.27^{*}$ \\
12.60 & 501.49 & 2.29 \\
20.56 & 512.33 & 2.36 \\
22.80 & 576.27 & 2.47 \\
22.83 & 519.93 & 2.36 \\
31.40 & 372.52 & 1.70 \\
48.80 & 638.28 & 2.34 \\
\hline
\end{tabular}

*Values are averages of three replications. Standard deviations are between $6 \%$ and $15 \%$ of the average.

Table 4. Specific energy requirements to reach $350 \mathrm{~kg} / \mathrm{m}^{3}$ wet matter bulk density.

\begin{tabular}{ccc|}
\hline Moisture (\% w.b.) & Pressure to reach $350 \mathrm{~kg} / \mathrm{m}^{3}(\mathrm{kPa})$ & Specific Energy Requirement $(\mathrm{kJ} / \mathrm{kg})$ \\
\hline 4.74 & $461.09^{*}$ & $1.98^{*}$ \\
12.60 & 466.27 & 1.91 \\
20.56 & 302.53 & 1.33 \\
22.80 & 278.84 & 1.17 \\
22.83 & 229.60 & 1.04 \\
31.40 & 175.80 & 0.75 \\
48.80 & 133.31 & 0.55 \\
\hline
\end{tabular}

*Values are averages of three replications. Standard deviations are between $6 \%$ and $15 \%$ of the average.

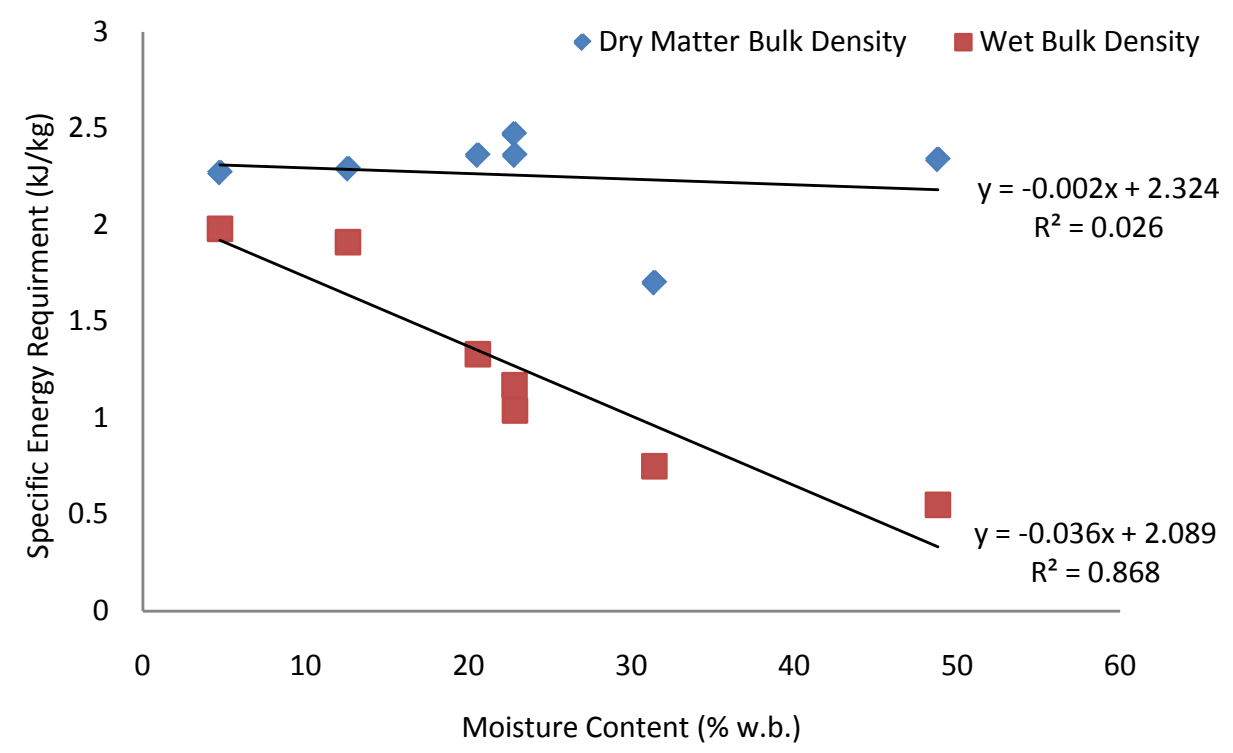

Figure 3. Moisture content verse specific energy requirement.

fall harvested switchgrass. To statistically prove that the switchgrass from spring did require more energy to compress, the specific energy requirements were calculated from the curves of compression force-displacement and compared to the same energy requirements from the fall harvested switchgrass. Since the compression testing of the various moisture contents determined there was no difference in the energy requirements to compress the switchgrass when only the dry matter was considered, both the fall and spring harvested tested were compared in terms of dry matter. This comparison can be seen in Table 5. 
Table 5. Specific energy requirements to reach $350 \mathrm{~kg} / \mathrm{m}^{3}$ for both the Agronomy Farm and Ernst switchgrass in terms of dry matter bulk density.

\begin{tabular}{cccc}
\hline Sample Source & $\begin{array}{c}\text { Moisture } \\
\text { (\% w.b.) }\end{array}$ & $\begin{array}{c}\text { Pressure to Reach } 350 \mathrm{~kg} / \mathrm{m}^{3} \\
(\mathrm{kPa})\end{array}$ & $\begin{array}{c}\text { Specific Energy Requirement } \\
(\mathrm{kJ} / \mathrm{kg})\end{array}$ \\
\hline & 4.7 & $529.1^{*}$ & $2.3^{*}$ \\
& 12.6 & 501.5 & 2.3 \\
Penn State Univ. Agronomy Farm & 20.6 & 512.3 & 2.4 \\
(Fall Harvesting) & 22.8 & 576.3 & 2.5 \\
& 22.8 & 519.9 & 2.4 \\
\hline
\end{tabular}

*Values are averages of three replications. Standard deviations are between $6 \%$ and $15 \%$ of the average.

\subsection{Discussion}

The increase in specific energy requirements of the spring harvested switchgrass are attributed to the fact that the switchgrass was mowed and laid on ground for an entire winter. This caused both physical and chemical changes to the biomass. The largest change occurred was the stalk to leaf ratio of the switchgrass. Mechanically harvesting switchgrass causes greater mass loss in leaves than stalks. When the switchgrass overwinters on the ground the leaves tend to become disjointed from the stalk and settle close to the ground. The leaves eventually degrade or settle and become unattainable for the harvest equipment. Research in Canada has shown that there was approximately a 66\% reduction in leaves in the composition the spring harvested switchgrass as compared to fall harvested switchgrass [11]. The reduction in leaf matter is primarily responsible for the reduction in yield that occurs when the switchgrass was harvested in the spring, as discussed earlier. This resulted in spring harvested biomass that contained a much lower percentage of leaves than the biomass obtained from the agronomy farm in the fall. The greater the percentage of stalks in herbaceous biomass, the harder the material becomes to compress [7]. Chemical changes caused the stems to become brittle and less pliable and also have an impact on the compression process.

\section{Conclusions}

The lab compression tests were used to quantify the energy requirements needed for switchgrass compression. The tests found that the moisture content of the switchgrass did not have any effect on the energy required to compress the switchgrass when only the dry matter bulk density is taken into account. The wetter switchgrass could be compressed to a higher wet bulk density for any given pressure only because of the moisture contained in the biomass. When baling switchgrass, the dry matter bulk density of the bales will not be influenced by the moisture content. Bales of higher moisture content will have a higher wet bulk density due to the increased water content and possibly changes in the frictional coefficient between the bale and the bale chamber that causes the plunger to unintentionally exert more force on the bale as it is being formed.

The time of the year that switchgrass is harvested will have a great impact on the characteristics of the biomass. The compression test showed that the decrease in leaf matter caused the spring harvested switchgrass to be much harder to compress as opposed to the fall harvested switchgrass. Switchgrass fields harvested in the fall will not only yield more dry matter, but will also have the ability to be formed into denser large square bales.

The main objective of both large square balers and bale compressors is to form a dense product that can be easily handled and transported. However, based on the specific energy requirements calculated from the lab compression tests, it is believed that the energy consumed by large square balers and bale compressors will be much less if bale in the fall than in the spring.

\section{References}

[1] Sokhansanj, S. (2009) Large-Scale Production, Harvest and Logistics of Switchgrass (Panicumvirgatum L.)—Current 
Technology and Envisioning a Mature Technology. Biofuels, Bioproducts \& Biorefining, 3, 124-141.

[2] Kumar, P.K. and Ileleji, K.E. (2009) Techno-Economic Analysis of the Transportation, Storage, and Handling Requirments for Suppling Lignocellulosic Biomass Feedstocks for Ethanol Production. ASABE Paper No. 097427, ASABE, St. Joseph.

[3] Sokhansanj, S. (2004) Biomass Densification-Cubing Operations and Costs for Corn Stover. Applied Engineering in Agriculture, 20, 495-499. http://dx.doi.org/10.13031/2013.16480

[4] Cundiff, J.S. and Marsh, L.S. (1996) Harvest and Storage Costs for Bales of Switchgrass in the Southeastern United States. Bioresource Technology, 56, 95-101. http://dx.doi.org/10.1016/0960-8524(95)00166-2

[5] Lam, P.S., Sokhansanj, S., Bi, X., Lim, C.J., Naimi, L.J., Hoque, M., Mani, S., Womac, A.R., Ye, X.P. and Narayan, S. (2008) Bulk Density of Wet and Dry Wheat Straw and Switchgrass Particles. Applied Engineering in Agriculture, 24, 351-358. http://dx.doi.org/10.13031/2013.24490

[6] Kalminski, T. (1989) Investigation of the Feasibility of Collection, Densification, Storage, Transportation, and Marketing of Agricultural Biomass. SRC Publications, Regina, Saskatchewan, 22-60.

[7] Van Pelt, T.J. (2003) Maize, Soybean, and Alfalfa Biomass Densification. CIGR Journal of Scientific Research and Development, 5, 1-17.

[8] Steffen Systems (2009) High Density Bale Compression Systems. http://www.steffensystems.com/bale-conversion-systems.php

[9] Miles, T. (2008) Communications with T. R. Miles. Technical Consultants, Inc. http://www.trmiles.com

[10] ANSI/ASAE S358.3 (2012) Moisture Measurement-Forages. ASABE, St. Joseph.

[11] REAP-Canada (2008) Optimization of Switchgrass Managment for Commercial Fuel Pellet Production. http://www.reap-canada.com/online_library 
Scientific Research Publishing (SCIRP) is one of the largest Open Access journal publishers. It is currently publishing more than 200 open access, online, peer-reviewed journals covering a wide range of academic disciplines. SCIRP serves the worldwide academic communities and contributes to the progress and application of science with its publication.

Other selected journals from SCIRP are listed as below. Submit your manuscript to us via either submit@scirp.org or Online Submission Portal.
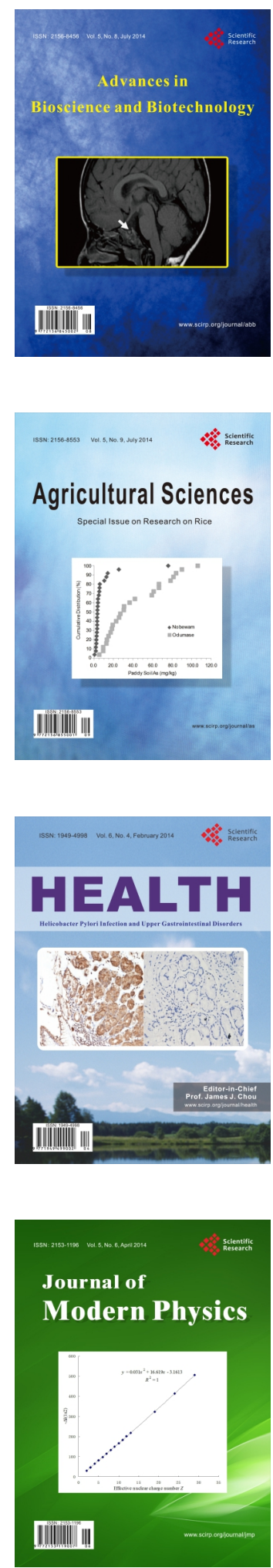
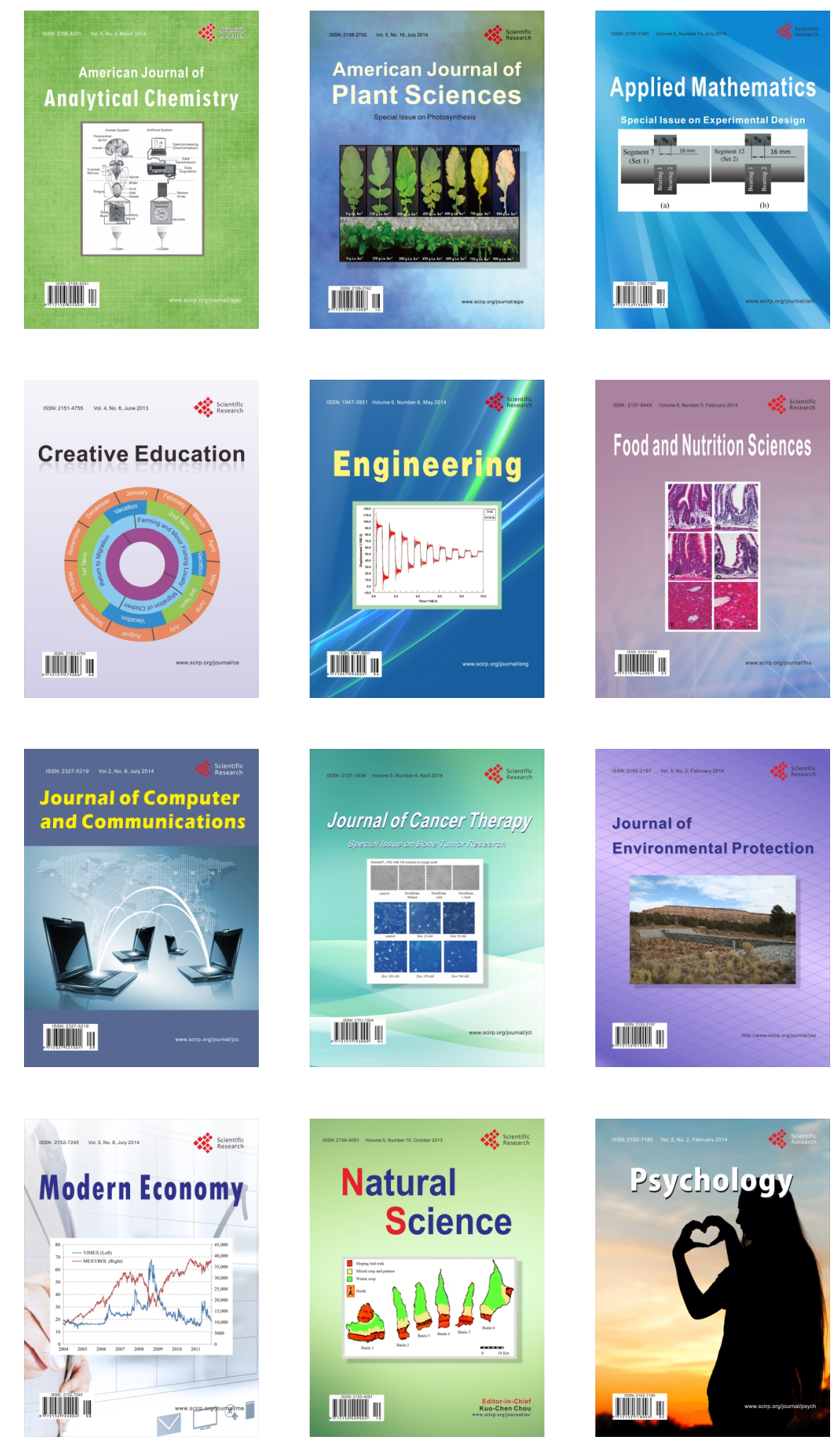